\title{
Adaptation and Appropriation in Aimé Césaire's a Tempest
}

\author{
Raad Kareem Abd-Aun, PhD \\ Assist. Prof. , University of Babylon, Iraq. \\ Qaiser Munir Diab, BEd \\ Independent Researcher.
}

\begin{abstract}
Aimé Césaire's A Tempest is one of the earliest adaptations of a Western canonical work. It is an adaptation of Shakespeare's The Tempest. Césaire's play conveys his anti-colonist ideas, exploring the relationship between Prospero, the colonizer, and his colonial subjects, Caliban and Ariel, from the perspective of the colonized. Comparing the characterization and the colonizer/colonized relationship in the two plays, this paper attempts to illustrate how Césaire uses Shakespeare's text to address the ills of colonialism and turn the tables on the colonizer using one of the masterpieces of the western canon. It also attempts to show how Césaire uses the mechanics of adaptation and appropriation to achieve his goals.
\end{abstract}

Keywords: adaptation; appropriation; Césaire, Aimé; A Tempest.

\section{Introduction}

Adaptation is the ability to make fit or suitable by changing, or adjusting, modifying something to create a change in structure, function, and form, which produces a better adjustment and to adapt means to transpose from one medium or genre (e.g. a novel, short story, poem) to another genre or medium, such as a film or stage play. It can also involve adapting the same literary work in the same genre or medium, just for different purposes. It is defined by Julie Sanders as "a specific process involving the transition from one genre to another: novels into film; drama into musical; dramatization of prose narratives and prose fiction; or the inverse movement of making drama into prose narrative" (2007, p. 17-18).

Appropriation means borrowing, imitating, taking over or using someone's idea or concept as a raw material to produce something original or at least something evidently different (Massai, 2007).

It is noticed that in both cases of adaptation and appropriation a generic shift may or may not happen. Also, these two terms in many ways "intersect and interrelate, yet it is equally important to maintain some clear distinctions between them as creative activities" (Massai, 2007).

In the process of adaptation, we have a clear and obvious signal and relationship with an informing source text (the original text). While in the appropriation process, the case is somehow different because the appropriated texts do not have that clear or obvious signal or relationship with the original text. Also, adaptations are obviously a re-reading or interpretation of a text while appropriations are more subtle. In adaptations, we often have a cultural change involved, an updating of the text for current audiences, or a different context while appropriations are less explicit and the text is often re-interpreted through political or ethical lenses. Appropriation constitutes sustained engagement with the text, but often adopts "a posture of critique (perhaps even assault)" (Nicklas \& Lindner, 2012, p. 25).

In the late twentieth century, "avant-garde" writings offer a scenario in which ability or even necessity of being "original" is questioned in the domain of arts and literature, so the old question "imitation or originality" becomes, therefor, redundant from the perspective of adaptation and appropriation. Edward Said suggested on originality that "the writer thinks less of writing originally, and more of rewriting" (as cited in Kundu, 2008, p. 388-389). 


\section{Adaptation and Appropriation in Aimé Césaire's A Tempest}

One of the writers who made use of adaptation and appropriation in his works was Aimé Césaire. He was a poet, playwright and a politician; also, he was one of the most influential Francophone Caribbean writers of his generation. Aimé Césaire was one of the founding fathers of Negritude, this concept or movement is defined as "affirmation that one is black and proud of it" (as cited in Lam, 2013, p. 302).

The black consciousness movement has sought to "assert pride in African cultural values to counterbalance the inferior status accorded to them in European colonial thinking" (Thieme, 2008).

Césaire saw Negritude as a "historical phenomenon that had evolved from commonalities in the post-colonial history of African peoples, particularly the experience of the Atlantic slave ships and plantation slavery" (Thieme, 2008).

Aimé Césaire's A Tempest deals with colonialism, and in this play, he discusses his idea of Negritude. It is a call for freedom and a reflection of the ways of how to get freedom. In this play, Césaire not only "re-reads and re-writes Shakespeare's The Tempest but expresses one of the most fundamental concerns of postcolonial literature; the effects of place and displacement on both the colonizer's and the colonized's sense of identity" (Maricondi, 1996, p. 47).

William Shakespeare's The Tempest possesses some "European biases in the justification of colonization among the colonized countries while Aimé Césaire's A Tempest is written as a postcolonial response to William Shakespeare's The Tempest and embodies the spirit of rebellion of the oppressed peoples against the European colonization" (Guo, 2008, p. 13).

Césaire's version of this play explores in further depth and studies thoroughly the original concepts and themes of colonialism and Negritude, which Césaire studied extensively. A Tempest addresses modernist issues and theories such as colonialism, racism and color discrimination through the utilization of a classic play most modern readers are familiar with (Césaire, 1972).

Post-colonial theatre is used as an anti-imperial tool, as a forefront for struggle against colonization and its implications, because of its own strong public dimension. All the playwrights from decolonized areas share the same project of dismantling the colonizer's rule, and influence. Colonization used literature as a weapon of cultural control to influence the native and to increase the status and superiority of European cultures. A need arose to evoke the point of view of the colonized through counter-colonial discourse (Memmi, 1991).

In this adaptation the main theme is changed, the protagonist is changed and the narration is changed and as such it deals much more with the story from the point of view of Caliban and Ariel. In making A Tempest an adaptation for black theater, Césaire suggests his governing principle: the master/slave relationship. This relationship between the colonizer and the colonized in Aimé Césaire's A Tempest is manifested clearly through two major characters, Prospero and Caliban, the former is the representative of colonizers while the latter is the representative of the colonized (Dixit, 2015).

Caliban is portrayed as an oppressed native and a rebel against colonization, fighting vigorously through various means to achieve his ultimate goal, freedom. The colonizer, Prospero, on the other hand is portrayed as the exploitative usurper of self-determinism, land, property, dignity, and even identity of the colonized peoples. This struggle between the colonizer (Prospero) and the colonized (Caliban) creates the main conflict in the play (James, 1978).

Aimé Césaire replaces the article "the" with "a" suggesting a singular storm rather than a universal one. The title of Aimé Césaire's play, A Tempest, is a deconstruction of the title of William Shakespeare's play, The Tempest. In addition, the title $A$ Tempest may suggest that the storm is not a creation of the magician Prospero (the colonizer); instead, it is a natural ongoing process and a regular phenomenon and this undermines the power of the colonizer (Prospero). It may also suggest the change in the black society through destruction and regeneration (James, 1978).

In this play, Aimé Césaire designed Caliban as a black slave, Ariel as a mulatto because mulatto slaves were traditionally viewed as better treated and he puts them on an island in order to set the action within a recognizable set of Caribbean problems of material and cultural dominance (Keane, 2014). 
It is noticed in this play that Aimé Césaire transforms the characters and transposes the scenes to reveal Prospero as the exploitative power-hungry European colonizer who exploits not only the land but also the minds of the colonized, and Caliban and Ariel as the exploited natives (Bakshi, Sengupta, \& Pau, 2009).

In Shakespeare's The Tempest, Caliban is seen as an offspring of the witch Sycorax, and servant of the noble wizard Prospero who views Caliban as "Nurture can never stick; on whom my pains\ Humanely taken - all, all lost, quite lost! And, as with age his body uglier grows,। So his mind cankers" (Shakespeare, 1999, p. 257). Contrary to Shakespeare's Caliban, Césaire's Caliban is completely different. He is seen as a colonized black native whose land has been taken and whose language and culture Prospero's has displaced. Césaire's Caliban is much more vocal and articulate, and his arguments for freedom are much forceful and to the point, revealing his strong indignation towards being conquered and enslaved (MoralsDaz, 2006):

Caliban: That is right, that is right! In the beginning, the gentleman was all sweet talk: dear Caliban here, my little Caliban there! And what do you think you'd have done without me in this strange land? Ingrate! I taught you the trees, fruits, birds, the seasons, and now you don't give a damn ... Caliban the animal, Caliban the slave! I know that story! Once you have squeezed the juice from the orange, you toss the rind away!

Prospero: Oh!

Caliban: Do I lie? Isn't it true that you threw me out of your house and made me live in a filthy cave. The ghetto! (Césaire, 1992, p. 13)

In Césaire's A Tempest, Prospero is portrayed as a slave-driving exploiter who is preying on Caliban's and Arial's weaknesses and using his power to deprive them of their freedom and make them obey him even if they do not like it (Innes, 2007):

Prospero: Well Ariel!

Ariel: Mission accomplished.

Prospero: Bravo, good work! .... Are you tired?

Ariel: Not tired; disgust, I obeyed you but - well, why not come with it? - I did so much unwillingly. It was a real pain to see the great ship go down, so full of life (Césaire, 1992, p. 9).

In this conversation, we see that Prospero has ordered Arial to crash the ship that holds the king of Naples (Alonso). The main thing that should be noticed in this conversation is that Ariel did not want to do that but he had to do it. He cannot follow or listen to his heart. He has to follow only his master. He has to think about his master and his master's aims and wishes only (Innes, 2007):

Prospero: Oh, so you are upset, are you! It is always like that with you intellectuals! Who cares! What interests me is not your moods, but your deeds. Let us split: I will take the zeal.

Ariel: Master, I must beg you to spare me this kind of labor.

Prospero: (shouting) Listen and listen good! There is a task to be performed, and I do not care how it gets done (Césaire, 1992, p. 9-10).

The colonizers treated their slaves like animals, if not worse, and they had no respect for their cultures and traditions. Aimé Césaire tried to highlight this idea in the play through Prospero who insults Caliban's mother by calling her ("a ghoul") and shows no respect nor any regard to Caliban's native language (Shah, 2010):

Prospero: Mumbling your native language again! I have already told you, I do not like it. You could be polite at least; a simple "hello" would not kill you (Césaire, 1992, p. 11). 
The colonizers not only disrespect the traditions and cultures of the colonized people, but also have no regard for their identity. This idea is clearly seen through Caliban's extreme unhappiness with his name because it is associated with the savages and cannibals (Hymowitz, Ivor, \& Anderson, 2003):

Caliban: Put it this way: I am telling you from now on I will not answer the name Caliban.

Prospero: Where did you get that idea?

Caliban: Well, because Caliban is not my real name. It is as simple as that.

Prospero: Oh, I suppose it is mine!

Caliban: It is the name given by your hatred, and every time it is spoken, it is an insult (Césaire, 1992, p. 14-15).

It may be true that there were cannibals somewhere in Africa in Shakespeare's time. Nevertheless, it is not necessarily true that all the Africans were cannibals. Therefore, the politics behind the naming of Caliban in Shakespeare's The Tempest is harshly criticized in Aimé Césaire's $A$ Tempest. The name Caliban undoubtedly evokes criticism as it may refer to cannibal or savages and as a result we see Caliban contemptuously informs Prospero that he wishes to be called "X" (Frank, 2009):

Caliban: Call me X. That would be best like a man without a name - or, to be more precise, a man whose name has been stolen. You talk about history... well that is history, and everyone knows it! Every time you summon me, it reminds me of a basic fact, the fact that you have stolen everything from me, even my identity! Uhuru! (Césaire, 1992, p. 15)

Caliban's desire to be called "X" can be seen as the strongest act of resistance and a total rejection to the authority of the colonizer (Prospero). It is impossible not to specifically identify Caliban with Malcolm $\mathrm{X}$ who was an African-American Muslim minister, a human rights activist and a courageous advocate for the rights of blacks, or any number of other Black radicals in many countries who assumed the role of revolutionaries. Aimé Césaire is trying to de-mystify the old myths about the Africans as cannibals, savages, animalistic, lustful and childlike people and tries to portray them as they are through the characterization of Caliban (Rider, 1999).

Language is an important tool to fight back and to represent self and race. The language in which Prospero commands Caliban is also used by both Shakespeare's and Césaire's Caliban but with a difference. In Shakespeare's The Tempest, Caliban is seen as the victim of the language he has been taught, and he only has the ability to represent his powerlessness and express his resentment (Rahman, 2015):

Caliban: You taught me language, and my profit on't

Is I know how to curse. The red plague rid you

For learning me your language.

Prospero: Hag-seed, hence

Fetch us in fuel, and be quick — thou'rt best -

To answer other business. Shrug'st thou, malice?

If thou neglect'st, or dost unwillingly

What I command, I will rack thee with old cramps,

Fill all thy bones with aches, make thee roar,

That beasts shall tremble at thy din.

Caliban: No, pray thee. 
[aside] I must obey; his art is of such power (Shakespeare, 176).

However, the case is different with Césaire's Caliban and the language Prospero teaches him becomes more than a tool to curse. It becomes a tool for him to voice his resistance and charge against the colonizer also we see him use colorful phrases and double meanings of words to almost make a mockery of Prospero out of the language he has been taught (Patterson, 2008):

Caliban: Uhuru!

Prospero: What did you say?

Caliban: I said, Uhuru!

Prospero: Mumbling your native language again! I have already told you, I don't like it. You could be polite, at least; a simple "hello" wouldn't kill you.

Caliban: Oh, I forgot... But make that as froggy, waspish, pustular and dung-filled "hello" as possible. May today hasten by a decade the day when all the birds of the sky and beasts of the earth will feast upon your corpse!

Prospero: Gracious as always, you ugly ape! How can anyone be so ugly?

Caliban: You think I am ugly....well, I do not think you are so handsome yourself. With that big hooked nose, you look just like some old vulture. (Laughing) an old vulture with a scrawny neck! (Césaire, 1992, p. 11)

In this conversation, Prospero scolds Caliban for using "Uhuru" instead of "hello" and describes it "mumbling". This may suggest two important things: First Prospero does not understand the native language of the colonized (Caliban) and at the same time he does not want to understand the meaning of "Uhuru" as it is a threat for him because once the language is accepted as intelligible and worthy of rational meaning, it will claim the same status as Prospero's own. Caliban's answer in this instance is stronger and he fights back labeling the language of the colonizer Prospero as nothing more than gibberish (Patterson, 2008):

Prospero: Since you are so fond of invective, you could at least thank me for having taught you to speak at all. You, a savage ... a dumb animal, a beast I educated, trained, dragged up from the bestiality that still clings to you.

Caliban: In the first place, that is not true. You did not teach me a thing! Except to jabber in your own language so that I could understand your orders: chop the wood, wash the dishes, fish for food, plant vegetables, all because you're too lazy to do it yourself. And as for your learning, did you ever impart any of that to me? No, you took care not to. All your science you keep for yourself alone, shut up in those big books. (Césaire, 1992, p. 11-12)

Therefore, we notice that Caliban's language seems mumbling to Prospero and at the same time Prospero's language is nothing more than gibberish to Caliban. As to the process of being forced to consume Prospero's language and culture, Césaire's Caliban finds it disgusting and wants to vomit and get rid of Prospero's white poison and this is obviously a clear rejection of the colonial authority and culture (Patterson, 2008). The colonizer thinks himself a savior for the colonized people by imposing his language and values upon them because he sees them as nothing more than savages who need saving. Therefore, when Prospero enslaves Caliban and Ariel, he considers himself their benefactor (Patterson, 2008):

Ariel: You have promised me my freedom a thousand times, and I am still waiting.

Prospero: Ingrate! And who freed you from Sycorax, may I ask? Who rent the pine in which you had been imprisoned and brought you forth? You will get it when I am good and ready. ...

Prospero: What would you be without me? ...

Prospero: Ten times, a hundred times, I have tried to save you, above all from yourself. (Césaire, 1992, pp. 10,12, 67) 
Both Caliban and Arial are fighting for their freedom but each one takes a different approach to achieve this goal. When compared with Caliban, we see that Arial's understanding of freedom is at a high level but he is somewhat accommodating and idealistic, trying to awake Prospero's conscience and hoping that Caliban and he can join up and fight for their freedom, but in some non-violent way (Douglas, 1972):

Ariel: You know very well that that's not what I mean. No violence, no submission either. Listen to me: Prospero is the one we have to change. Destroy his serenity so that he is finally forced to acknowledge his own injustice and put an end to it.

Caliban: Oh sure ... that is a good one! Prospero's conscience! Prospero is an old scoundrel who has no conscience.

Ariel: Exactly - that's why it's up to us to give him one! I am not fighting just for my freedom, for our freedom, but for Prospero too, so that Prospero can acquire a conscience: Help me, Caliban. (Césaire, 1992, p. 22)

Césaire's Arial is nothing like Shakespeare's Arial who is submissive and obedient to Prospero and seems to care for nothing but his own freedom. Ariel in A Tempest is less willing to carry out Prospero's missions and he makes this known to Prospero when he shows sympathy for the victims of Prospero's tempest (O'Toole, n.d.):

Prospero: Enough hairsplitting! My mood has changed! They insult me by not eating. They must be made to eat out of my hand like chicks. That is a sign of submission I insist they give me.

Arial: It is evil to play with their hunger as you do with their anxieties and their hopes. (Césaire, 1992, p. 28)

On the other hand, Caliban deals with Prospero in a more intense way than Arial and his resistance is by far more forceful than that of Ariel's. Caliban seems to know Prospero better than Ariel, also he has no belief in Prospero's conscience. He shows great courage and determination despite all the terror to the extent that he is ready to sacrifice his own life to get his freedom (O'Toole, n.d.):

Caliban: You do not understand a thing about Prospero.

$\mathrm{He}$ is not the collaborating type. He is a guy who only feels something when he's wiped someone out. A crusher, a pulveriser, that is what he is! And you talk about brotherhood!

Ariel: So then, what is left? War? And you know that when it comes to that, Prospero is invincible.

Caliban: Better death than humiliation and injustice. (Césaire, 1992, p. 23)

Like Shakespeare's Caliban, Césaire's Caliban also formulates a plan with Stephano and Trinculo to win back his freedom. Caliban's plot to overthrow Prospero in both Shakespeare's and Césaire's plays are almost the same concerning its process and result, but there are some differences as far as the purpose is concerned. Shakespeare's Caliban is not civilized enough to sense the possibility of liberty. He only knows that his master treats him badly and his hatred to his master is what derives him to take revenge upon him. In addition to that, his scheme is very simple and it almost ends before starting. In the process, Shakespeare's Caliban is rightly humiliated and punished when he is dumped in horse-urine. He even recognizes that his rebellion was a sin against the law of God and nature and the great chain of being and he ends his role by calling himself a fool to take a drunken man as a god which indicates that Caliban becomes an obedient and passive slave (O'Toole, n.d.): "Caliban: Ay, that I will; and I will be wise here after and seek for grace. What a thrice-double ass was I to take this drunkard for a god, and worship this dull fool" (Shakespeare, 1999, p. 283).

However, in Césaire's A Tempest, the case is very different and Caliban's plot against Prospero is clearly meant to make him win his freedom. Nevertheless, as he starts to carry it out with the hope of joint force from Stephano and Trinculo, two drunkards who make themselves powerless and senseless with alcohol, he begins to realize he has fallen in with fools when he says (Duckett, 2015): 
To think I am stuck with these jokers! What an idiot I am! How could I ever have thought I could create the Revolution with swollen guts and fat faces! Oh well! History will not blame me for not having been able to win my freedom all by myself. It is you and me, Prospero! (Césaire, 1992, p. 56)

Therefore, he decides to launch the battle alone against Prospero and with weapon in hand he charges towards Prospero. In his march, we see him singing a war song and this is a proof of the fact that Africa has cultural elements like poems and songs. In this song, he mentions Shango, the Yoruba god of thunder, to draw strength from him. Caliban's invocation of the god of thunder suggests that he is not submitting to Prospero and that the relationship between the master and the slave is going to be changed forever (Griffiths, 1983):

Prospero: Poor Caliban! You know that you are headed towards your own ruin. You are sliding towards suicide! You know I will be the stronger and stronger all the time. I pity you!

Caliban: And I hate you!

Prospero: Beware! My generosity has its limits.

Caliban: (shouting) Shango marches with strength along his path, the sky! Shango is a fire-bearer, his steps shake the heavens and the earth Shango, Shango, ho! (Césaire, 1992, p. 65-66)

Aimé Césaire's references to Shango (the god of thunder), Eshu (the black devil god) and some native words like Uhuru in several places of the play is very important because the use of these native words and representation of the native gods show his negritude and his fight against the representational politics about the blacks. In addition, these native words and gods are a good representation of the shared cultural heritages of the African people, which unite them and show who they truly are (Rahman, 2015).

In the last scene, after Caliban's revolution, Prospero, the colonizer, becomes weaker and weaker and is no longer his old self: "Time passes, symbolized by the curtain's being lowered halfway and reraised. In semi-darkness Prospero appears, aged and weary. His gestures are jerky and automatic, his speech weak, toneless, trite" (Césaire, 1992, p. 68). Caliban's speech after his failed revolution becomes a prophecy: "Caliban: Now I know you, you old cancer, and I also know myself! And I know that one day my bare fist, just that, will be enough to crush your world! The old world is crumbling down!" (Césaire, 1992, pp. 64-65)

Césaire hints that colonization is declining and that the colonizers are losing their power over the colonized people: "Well, I hate you as well! For it is you who have made me doubt myself for the first time" (Césaire, 1992, p. 66). This speech can be clearly viewed as a moral victory for Caliban (the colonized) over Prospero (the colonizer).

Césaire makes his voice heard most clearly through Caliban's speech which is an eloquent accusation against colonization:

Caliban: You are a great magician: you are an old hand at deception ... And you lied to me so much, about the world, about myself, that you ended up by imposing on me an image of myself: an image of myself: underdeveloped, in your words, under competent that is how you made me see myself! And I hate that image ... and it's false! (Césaire, 1992, p. 64)

It is this false image that Césaire wants to decolonize transforming Caliban from Shakespeare's ignorant savage to a colonized native with black consciousness (Manzanas \& Benito, 1999).

Finally, in A Tempest, Césaire gives the privilege to Caliban to end the play with his song, which is printed in capital letters demonstrating his (the colonized) victory and triumph over Prospero (the colonizer). He is no longer traceless or overshadowed and even though he does not appear on stage but everybody hears his voice. The stage of the world belongs to all without any discrimination at all. It is the word "FREEDOM" that Césaire wants everyone, the colonized and the colonizer alike, to hear. It is a cry for freedom or decolonization all over the world (Manzanas \& Benito, 1999): "FREEDOM HI-DAY, FREEDOM HI-DAY!" (Césaire, 1992, p. 68)

III. Conclusion 
In order to convey his themes, Aimé Césaire has adapted and appropriated in his own style one of the most famous western canonical work, which is William Shakespeare's The Tempest in order to demystify the myths about the black people. Shakespeare wrote The Tempest for his audience from the colonizer's stand while Césaire wrote A Tempest for both the colonizer and the colonized taking sides with the latter. The character of Prospero in Shakespeare's The Tempest can be seen to represent the alter ego of Shakespeare and similarly, Caliban and Arial in Aimé Césaire's A Tempest can be seen to represent the mouthpiece of Césaire and the tool through which he counters Shakespeare's ideas. What Caliban says and does against Prospero is the mirror image of what Césaire does to Shakespeare.

Aimé Césaire in his play A Tempest introduces some of the many ills and faults of colonial domination. In rejecting colonialism, he expresses the view that there is no dignity without freedom. Nevertheless, the freedom, which Césaire speaks about, is not only the simple freedom from the oppressive physical presence of the colonizer, but it is also the freedom from the psychological bonds, which so many colonized people have accepted.

The basic thing, which Aimé Césaire wants to convey in A Tempest and the rest of his writings, is his wish to see black people united, not in their acceptance of inferiority, but in their rejection of an inferior status, and such is his basic concept of political Negritude. In addition, this concept is achieved through his characterizations of Prospero, Caliban and Ariel. Césaire presents his anti-colonial attitude and injects black consciousness into the colonized. Moreover, Césaire's thinking on the possibilities to gain freedom is implied in Caliban's and Ariel's struggle for their freedom. A Tempest, above all, is a call to get rid from the shackles or chains of servitude and a loud cry for consciousness of freedom.

\section{Bibliography}

[1] Bakshi Kaustav, Samrat Sengupta, Subhadeep Pau. (2009). Anxieties, Influences and After: Critical Responses to Postcolonialism and Neocolonialism. New Delhi: Worldview Publications.

[2] Césaire, Aimé. (1972). Discourse on Colonialism, translated by Joan Pinkham. London: Monthly Review Press.

[3] Césaire, Aimé. (1992). A Tempest. Translated by Richard Miller. New York: Ubu Repertory Theater Publication.

[4] Douglas, J. (1972). A Study of the Black Political Theater of Amie Césaire. Ontario: McMaster University.

[5] Duckett, Katharine. (Mar. 23, 2015). Unreliable Histories: Language as Power in The Tempest. Tor.com. Retrieved from http://www.tor.com/2015/03/23/unreliable-histories-language-as-power-in-the-tempest/ (accessed October 19, 2015).

[6] Frank, Katherine. (n.d.) Shakespeare on Global Colonialism. Retrieved from http://www2.cedarcrest.edu/academic/eng/ffletcher/tempest/papers/Kafrank.htm (Accessed October 18, 2015).

[7] Griffiths, Trevor. (1983). 'This Island's mine': Caliban and Colonialism. The Yearbook of English Studies 13, 159180. Stable URL: http://www.jstor.org/stable/3508119

[8] Guo, Yuehua. (2008). A Rebel against Colonization: A Comparative Study of Césaire's Caliban in A Tempest with Shakespeare's Caliban in the Tempest. Asian Social Science 2(4), 13-16. doi: http://dx.doi.org/10.5539/ass.v4n2p13

[9] Hymowitz, Sarah, Dikkers, Ivor, \& Amalia, Anderson. (2003). Study Guide: The Rights of Indigenous Peoples. Retrieved from http://hrlibrary.umn.edu/edumat/studyguides/indigenous.html

[10] Innes, Lyn. (2007). The Cambridge Introduction to Post Colonial Literatures in English. Cambridge: Cambridge University Press.

[11] James, A. Arnold. (1978). Césaire and Shakespeare: Two Tempests. Comparative Literature 30(3), 236-248. doi: $10.2307 / 1770825$

[12] Keane, Patrick. (2014) Identity and Difference: Coleridge and Defoe, Crusoe and Friday, Prospero and Caliban: Essay. Numéro Cinq V(3). Retrieved from http://numerocinqmagazine.com/2014/03/11/identity-anddifference-coleridge-and-defoe-crusoe-and-friday-prospero-and-caliban-essay-patrick-j-keane-2/ (Accessed October 17, 2015).

[13] Kundu, Rama. (2008). Intertext: A Study of the Dialogue Between Texts. New Delhi: Sarup \& Sons. 
[14] Linsley, Robert. (2013). Wilfredo Lam: Painter of Negritude. In Kymberly N. Pinder (Ed.), Race-ing Art History: Critical Readings in Race and Art History (289-306). London \& New York: Routledge.

[15] Manzanas, Ana, \& Jesús, Benito. (1999). Narratives of Resistance: Literature and Ethnicity in the United States and the Caribbean. Albacete: Univ de Castilla La Mancha.

[16] Massai, Sonia. (2007). World-Wide Shakespeares: Local Appropriations in Film and Performance. London: Routledge.

[17] Memmi, Albert. (1991). The Colonizer and the Colonized. London: Routledge.

[18] Morales-Daz, Enrique. (2006). Calibanesque Revolution in Reinaldo Arenas Writing. Postcolonial Text 2(2). Retrieved from http://postcolonial.org/index.php/pct/article/view/258/772 (Accessed October 18, 2015).

[19] Nicklas, Pascal, Oliver, Lindner. (2012) Adaptation and Cultural Appropriation: Literature, Film, and the Arts. Berlin: Walter de Gruyter.

[20] O'Toole, Michael. (2011). Shakespeare's Natives: Ariel and Caliban in The Tempest. Quixotic. Retrieved from http://www.columbia.edu/itc/lithum/gallo/tempest.html (Accessed October 19, 2015).

[21] Patterson, Jeanette. (2008). Au pire: Language, Violence and the Totalitarian Ideology of Origins in lonesco's La leçon and Césaire's Une tempête. French Forum 33(1-2), 195-213. doi: 10.1353/frf.0.0044

[22] Rahman, Mohammad Kasifur. (2015). Manifestation of Resistance through Caliban in Aimé Césaire's A Tempest. Global Journal of Human-Social Science 15(4), 7-10. Retrieved from https://globaljournals.org/journals/human-social-science/a-arts-humanities-psychology

[23] Rider, Shawn. (n.d.). Confronting the Stage: M. Butterfly and A Tempest as Examples of Postcolonial Drama. Retrieved from http://www.wdog.com/rider/writings/butterfly_tempest.htm (accessed October 18, 2015).

[24] Sanders, Julie. (2007). Adaptation and Appropriation. London: Routledge.

[25] Sanders, Julie. (2014). What is Adaptation? Retrieved from http://globalshakespearesbu.blogspot.com/2014/11/juliesanders-what-is-adaptation.html (accessed September 12, 2015).

[26] Shah, Anup. (Oct. 2101). Rights of Indigenous People. Global Issues. Retrieved from http://www.globalissues.org/article/693/rights-of-indigenous-people (accessed October 18, 2015)

[27] Shakespeare, William. (1999). The Tempest. Oxford: The Arden Shakespeare.

[28] Thieme, John. (19 April 2008). Aimé Césaire: Founding father of Negritude. The Independent. Retrieved from http://www.independent.co.uk/news/obituaries/Aimé-Césaire-founding-father-of-negritude-811812.html (Accessed September 17, 2015).

[29] Willoquet-Maricondi, Paula. (1996). African Animism, Négritude, and the Interdependence of Place and Being in Aimé Césaire's A Tempest. Interdisciplinary Studies in Literature and Environment 3(2), 47-61. doi: 10.1093/isle/3.2.47 